\title{
THE UN ‘NORMS ON THE RESPONSIBILITY OF TRANSNATIONAL CORPORATIONS AND OTHER BUSINESS ENTERPRISES WITH REGARD TO HUMAN RIGHTS': A REQUIEM
}

\author{
PINI PAVel MIRETSKI*
}

\section{SASCHA-DOMINIK BACHMANN**}

On 11 June 2011, the United Nations Human Rights Council endorsed the 'Guiding Principles for Business and Human Rights' as a new set of guiding principles for global business designed to provide a global standard for preventing and addressing the risk of adverse impacts on human rights linked to business activity. This outcome was preceded by an earlier unsuccessful attempt by a Sub-Commission of the UN Commission on Human Rights to win approval for a set of binding corporate human rights norms, the so called 'Norms on the Responsibilities of Transnational Corporations and Other Business Enterprises with Regard to Human Rights'. This article identifies and discusses the reasons why the Norms eventually failed to win approval by the then UN Commission on Human Rights. This discussion assists an understanding of the difficulties in establishing binding 'hard law' obligations for transnational corporations with regard to human rights within the wider framework of international law. It elucidates the possible motives as well as the underlying rationale which led first to the adoption and then the rapid abandoning of the Norms. The discussion also sheds light on the future of the voluntarism of business human rights compliance, on the likelihood of finding alternative solutions, and finally on the rationale for, and effect of, the 'Guiding Principles for Business and Human Rights'.

\footnotetext{
* BA, MA magna cum laude (Hebrew University), Faculty of Social Sciences, Department of International Relations, PhD candidate Hebrew University: pini.miretski@gmail.com.

** Assessor Juris, LLM (Stellenbosch), LLD (UJ), FHEA (UK); Reader in International Law, Lincoln Law School, University of Lincoln, United Kingdom: sbachmann@lincoln.ac.uk. The article was completed while Sascha worked for the University of Portsmouth, UK. The authors would like to thank Sasha-Lee Afrika, PhD candidate, University of Stellenbosch, RSA for her insightful comments and assistance.
} 


\section{INTRODUCTION AND OVERVIEW}

After endorsing the 2011 'Guiding Principles for Business and Human Rights', ${ }^{1}$ the Office of the UN High Commissioner for Human Rights issued a press release announcing that

in an unprecedented step, the United Nations Human Rights Council has endorsed a new set of Guiding Principles for Business and Human Rights designed to provide - for the first time - a global standard for preventing and addressing the risk of adverse impacts on human rights linked to business activity. ${ }^{2}$

While such a categorisation may be debatable, ${ }^{3}$ there remains little disagreement over the importance of such an endorsement by the UN Human Rights Council. The Secretary-General's Special Representative for Business and Human Rights (hereinafter SRSG), Professor John Ruggie, declared that ' $[t]$ he Council's endorsement establishes the Guiding Principles as the authoritative global reference point for business and human rights'. ${ }^{4}$ This was reinforced by the incorporation of the Guiding Principles and the 'Protect, Respect and Remedy' framework in the 2011 update of the OECD Guidelines for Multinational Enterprises. ${ }^{5}$ However, in order to fully understand the importance as well as the novelty of the framework, it is imperative to understand the drafting history leading to this seminal outcome for corporate human rights and particularly the initiative which was the basis for the establishment of the mandate of the SRSG. ${ }^{6}$

\footnotetext{
${ }^{1}$ These are the guiding principles for states and transnational corporations and other business entities on the implementation of Ruggie's 'Protect, Respect and Remedy' framework.

${ }^{2}$ UN Office of the High Commissioner for Human Rights, 'New Guiding Principles on Business and Human Rights Endorsed by the UN Human Rights Council' (Media Release 16 June 2011) [italics added]; for the full text of the Guiding Principles, see United Nations Human Rights Council, Report of the Special Representative of the Secretary-General on the Iissue of Human Rights and Transnational Corporations and other Business Enterprises, John Ruggie Guiding Principles on Business and Human Rights: Implementing the United Nations 'Protect, Respect and Remedy' Framework, $17^{\text {th }}$ sess, Agenda Item 3, UN Doc A/HRC/17/31 (21 March 2011); United Nations Human Rights Council, Resolution Adopted by the Human Rights Council: Human Rights and Transnational Corporations and Other Business Enterprises, $17^{\text {th }}$ sess, Agenda Item 3, UN Doc A/HRC/RES/17/4 (6 July 2011).

${ }^{3}$ See below Part 2 of this article for a discussion of previous standards of business and human rights relations.

${ }^{4}$ UN Office of the High Commissioner for Human Rights, above n 2.

5 Organization for Economic Co-Operation and Development, 'OECD Guidelines for Multinational Enterprises - 2011 Edition' (Guidelines, OECD 25 May 2011) ch IV.

6 John Gerard Ruggie, 'Business and Human Rights: The Evolving International Agenda' (2007) 101 American Journal of International Law 819, 821.
} 
In 1998 the Working Group on the Working Methods and Activities of Transnational Corporations was established by a Sub-Commission of the UN Commission on Human Rights. ${ }^{7}$ Its mandate was to make recommendations and proposals concerning the working methods and activities of transnational corporations (TNCs), in order to ensure that these correlate with the economic and social objectives of their host countries and promote human rights. ${ }^{8}$ The final detailed document, and its commentary, were approved in August 2003 by the Sub-Commission. The document was named the Norms on the Responsibilities of Transnational Corporations and Other Business Enterprises with Regard to Human Rights (hereinafter Norms). ${ }^{9}$ The Norms

\footnotetext{
7 Jakob Ragnwaldh and Paola Konopik, 'The UN Norms on the Responsibilities of Transnational Corporations and Other Business Enterprises with Regard to Human Rights' in Ramon Mullerat (ed), Corporate Social Responsibility: The Corporate Governance of the 21 st Century (Kluwer Law International 2005) 251-2; Dinah Shelton, 'Protecting Human Rights in a Globalized World' (2002) 25 Boston College International and Comparative Law Review 273, 284. The Sub-Commission on Prevention of Discrimination and Protection of Minorities was renamed in 1999 to be named the Sub-Commission on the Promotion and Protection of Human Rights. Sub-Commission on the Promotion and Protection of Human Rights, 'Sub-commission on the Promotion and Protection of Human Rights - Final Report of the $58^{\text {th }}$ session' UN GAOR, $58^{\text {th }}$ sess, UN Doc A/HRC/Sub.1/58/36, (11 September 2006).

8 Sub-Commission on Prevention of Discrimination and Protection of Minorities, The Relationship Between the Enjoyment of Economic, Social and Cultural Rights and the Right to Development, and the Working Methods and Activities of Transnational Corporations, ESCOR, 50 ${ }^{\text {th }}$ sess, $26^{\text {th }} \mathrm{mtg}$, UN Doc E/CN.4/Sub.2/1998/45(20 August 1998) [4(d)]. During the subsequent years, the mandate of the working group was expanded several times. In 2001 the mandate was extended for another three years, and the authority to compile a list of human rights instruments and norms pertaining to transnational corporations was included. SubCommission on the Promotion and Protection of Human Rights, The Effects of the Working Methods and Activities of Transnational Corporations on the Enjoyment of Human Rights, ESCOR, 53 ${ }^{\text {rd }}$ sess, $25^{\text {th }} \mathrm{mtg}$, UN Doc E/CN.4/Sub.2/2001/40 (15 August 2001).

9 Sub-Commission on the Promotion and Protection of Human Rights, Norms on the Responsibilities of Transnational Corporations and Other Business Enterprises with Regard to Human Rights, UN ESCOR, 55 $5^{\text {th }}$ sess, $22^{\text {nd }} \mathrm{mtg}$, Agenda Item 4, UN Doc E/CN.4/Sub.2/2003/12/Rev.2 (13 August 2003); Carolin F Hillemanns, 'UN Norms on the Responsibilities of Transnational Corporations and Other Business Enterprises with Regard to Human Rights' (2003) 4 German Law Journal 1065, 1071; David Weissbrodt and Muria Kruger, 'Norms on the Responsibilities of Transnational Corporations and Other Business Enterprises with Regard to Human Rights' (2003) 97 American Journal of International Law 901, 901-15; Larry Catá Backer, 'Multinational Corporations, Transnational Law: The United Nation's Norms on the Responsibilities of Transnational Corporations as Harbinger of Corporate Responsibility in International Law' (2006) 37 Columbia Human Rights Law Review 287, 287; Ruggie, above n 6, 820; David Kinley and Rachel Chambers, 'The UN Human Rights Norms for Corporations: The Private Implications of Public International Law' (2006) 6(3) Human Rights Law Review 447, 467-8; Olga Martin-Ortega, 'Business and Human Rights in Conflict' (2008) 22(3) Ethics \& International Affairs 273, 280-1; Troy Rule, 'Using Norms to Change International Law: UN Human Rights Laws Sneaking in through the Back Door' (2004) 5 Chicago Journal of International Law 325, 328.
} 
were far-reaching and included a duty for $\mathrm{TNCs}^{10}$ to impose human rights obligations upon states, even if states failed to ratify the human rights instruments establishing these duties. ${ }^{11}$

The draft Norms represented a significant departure from the prevailing practice among international organisations when dealing with the often difficult relationship between business and human rights: that of voluntary compliance. $^{12}$ The Norms were designed to constitute a 'non-voluntary', comprehensive framework, creating direct obligations for TNCs and supplemented by a rigid enforcement mechanism including the monitoring by non-state actors (NGOs and TNCs themselves). The document was prepared in accordance with the mandate that the Working Group received and was in line with the background reports upon which it was supposed to structure its work. Many scholars hailed the document as the groundbreaking initiative that might succeed, for the first time, in ending corporate abuses of human rights. $^{13}$

Such explicit support for the Norms was accompanied by often fierce opposition from various states and the majority of the business community.

\footnotetext{
${ }^{10}$ The term TNCs in this chapter relates also to other business enterprises, unless it is expressly stated otherwise. This term will be used interchangeably with the terms MNCs (multinational corporations) and MNEs (multinational enterprises).

${ }^{11}$ Backer, above n 9, 371-80; Ruggie, above n 6, 825-6; Kinley and Chambers, above n 9, 452.

12 Such approaches were prevalent within the UN Draft Code of Conduct for Transnational Corporations (UNCTC, Transnational Corporations, Services and the Uruguay Round (United Nations, 1990) 231-43 (see particularly art 4)); the International Labour Organization in the Tripartite Declaration (International Labour Organization, 'Tripartite Declaration of Principles Concerning Multinational Enterprises and Social Policy (MNE Declaration)'(ILO, 1977); International Labour Organization, 'Tripartite Declaration of Principles Concerning Multinational Enterprises and Social Policy (MNE Declaration) $-3^{\text {rd }}$ Edition', ILO, 1 January 2000); International Labour Organisation, 'Tripartite Declaration of Principles Concerning Multinational Enterprises and Social Policy (MNE Declaration) $-4^{\text {th }}$ Edition'(ILO, 1 January 2006); as well as in the OECD in its Guidelines for Multinational Enterprises (Joachim Karl, 'The OECD Guidelines for Multinational Enterprises' in Michael K Addo (ed), Human Rights Standards and the Responsibility of Transnational Corporations (Martinus Nijhoff Publishers, 1999) 98-106; Organization for Economic Co-Operation and Development, 'OECD Guidelines for Multinational Enterprises' (Guidelines, OECD, 27 June 2000); OECD, above n 5.

${ }^{13}$ See Surya Deva, 'UN's Human Rights Norms for Transnational Corporations and Other Business Enterprises: An Imperfect Step in the Right Direction' (2004) 10 ILSA Journal of International \& Comparative Law 493, 497; Julie Campagna, 'United Nations Norms on the Responsibilities of Transnational Corporations and Other Business Enterprises with Regard to Human Rights: The International Community Asserts Binding Law on the Global Rule Makers' (2004) 37 John Marshall Law Review 1205, 1205-52; Hillemanns, above n 9, 1065; Weissbrodt and Kruger, above n 9; David Weissbrodt, 'Business and Human Rights' (2005) 74 University of Cincinnati Law Review 55, 55.
} 
Such opposition arose from the moment the Norms were formally introduced as a discussion paper after their approval by the Sub-Commission. ${ }^{14}$ Most states expressed strong reservations, emphasising their determination not to depart from the traditional framework of international law, which stresses the central and pivotal role of the state as a legal subject of public international law.

The Norms were eventually abandoned in 2005 and the task of regulating transnational corporate accountability was transferred to other UN organs. ${ }^{15}$ This article discusses possible reasons why the Norms failed to be approved by the UN Commission on Human Rights. This discussion is necessary to help us understand the difficulties involved in creating 'hard law' obligations governing TNCs with regard to human rights within the wider framework of international law. It is crucial to understand the possible motives as well as the underlying rationale which led first to the adoption and then the rapid abandoning of the Norms. The discussion will also shed light on the future of indirect, vague voluntarism, as well as on our prospects of finding alternative solutions to the problems addressed by the Norms.

The Norms were defined by one of their drafters as a "non-voluntary set of norms binding upon corporations'. ${ }^{16}$ Deva expressed the importance of the Norms in the observation that they constituted a shift in paradigms 'that have to date dominated the discourse of corporate social responsibility' and have caused ineffective regulation of corporate conduct, resulting in abuses of human rights. ${ }^{17}$ The Norms were defined by their authors largely as a restatement of existing obligations of TNCs in respect to human rights under international law. However, some of the obligations in the Norms were a

\footnotetext{
${ }^{14}$ Sub-Commission on the Promotion and Protection of Human Rights, above $\mathrm{n} 9$.

15 The Commission decided that the Norms contained 'useful elements and ideas' but added that it had not requested them and that, as a draft proposal, they had no legal standing. The determination of several major industrialised countries to deal with the relationship between business and human rights ultimately resulted in the appointment of Ruggie to the post of special representative to the UN Secretary General, although with a significantly narrower mandate: Backer, above n 9, 288, 331-3; Ruggie, above n 6, 821; Kinley and Chambers, above n 9, 449; Martin-Ortega, above n 9, 281.

${ }^{16}$ Sub-Commision on the Promotion and Protection of Human Rights, above n 9; Hillemanns, above n 9, 1071; Weissbrodt and Kruger, above n 9, 901-15; Backer, above n 9, 287; Ruggie, above n 6, 820; Kinley and Chambers, above n 9, 467-8; Martin-Ortega, above n 9, 280-1; Rule, above n 9, 328.

${ }^{17}$ Deva, above n 13, 497; Hillemanns, above n 9, 1068. On the movement of corporate social responsibility and its development see Ronen Shamir, 'Capitalism, Governance, and Authority: The Case of Corporate Social Responsibility' (2010) 6 Annual Review of Law and Social Science 531, 531-53; David Vogel, 'Private Global Business Regulation' (2008) 11(1) Annual Review of Political Science 261, 261-82.
} 
teleological manifestation of an ongoing 'progressive development' of the existing principles of international law. ${ }^{18}$

Perhaps their main novelty, and possibly the main reason for the subsequent controversy over the Norms, was the fact that the obligations were to be imposed directly on TNCs, rather than states being requested or required to implement legislation to regulate the actions of the TNCs within their jurisdiction. While most of the rules in the Norms represented obligations already recognised within the existing frameworks of international law, in the vast majority of cases they are imposed only indirectly on TNCs, through the intermediary of the states. ${ }^{19}$ Baxi further argues that the Norms reflected duties that applied to states and that may not be automatically transposed to apply to TNCs. In that respect he believes that while the Norms may have embodied a good vision of de lege ferenda, or the law to which we may aspire, they did not reflect lex lata, or positive existing law. ${ }^{20}$

This article identifies three reasons which most likely led to the eventual abandoning of the draft Norms by the UN Commission on Human Rights: Firstly, the fact that a large part of the Norms constituted a further development of existing international norms, rather than actual codification of existing international law, enabled critics of the Norms to argue their incompatibility, as legal analogies, with otherwise positivist foundations of international law. Secondly, the fact that the Norms assigned an important legal role to TNCs (and MNCs - Multinational Corporations) rather than to the traditional addressees of international law, the states, was problematic. The construction of the TNCs as addressees blurred the distinction between international public and private legal frameworks, and thus undermined the central role of states as international law subjects. Finally, inherent contradictions within the Norms themselves and a vagueness in their overall nature and applicability helped to foster opposition against their adoption.

\footnotetext{
18 Weissbrodt and Kruger, above n 9, 913-15; Carlos M Vázquez, 'Direct vs Indirect Obligations of Corporations under International Law' (2005) 43 Columbia Journal of Transnational Law 927, 928; Rule, above n 9, 326; Hillemanns, above n 9, 1070.

${ }^{19}$ Examples of such documents and treaties are the Convention on the Elimination of All Forms of Discrimination against Women, and the OECD and UN anti-bribery conventions. See John Gerard Ruggie, Interim Report of the Special Representative of the Secretary-General on the Issue of Human Rights and Transnational Corporations and Other Business Enterprises, UN Doc E/CN.4/2006/97 (22 February 2006) [61]; Ruggie, above n 6, 822; Kinley and Chambers, above $n$ 9, 460; Vázquez, above n 18, 929-30.

${ }^{20}$ Upendra Baxi, 'Market Fundamentalisms: Business Ethics at the Altar of Human Rights' (2005) 5(1) Human Rights Law Review 1, 14.
} 
This article will first examine the reasons that led to the formal recognition of the necessity to create the Norms. Secondly it will comment on the drafting of the Norms with a focus on the stakeholder environment at the time of this process. The third Part will review the main features and novelties introduced in the draft document. ${ }^{21}$ Finally, the article will analyse the responses to the Norms, through examining their legal validity and justification.

\section{Legislative Context And Relevance of the NORMS}

The Norms aimed at 'maximizing the good that companies do while eliminating the abuses they commit'. ${ }^{22}$ Their rationale was to establish (and enforce) a balance between corporate business behaviour and human rights. Such a balance would acknowledge the positive role corporations can play in regard to economic development and overall prosperity, ${ }^{23}$ while preventing the occurrence of corporate human rights violations. One of its drafters, Professor Weissbrodt, argued that grave human rights abuses by corporations occur in a variety of business situations and consequently need to be regulated at the supranational level. ${ }^{24}$

As pointed out by Kinley and Chambers, the 1990s saw widening concerns with respect to increased violations of human rights by TNCs. These violations were occurring against a background of an increased liberalisation of international trade rules, the increase of foreign direct investment in developing and emerging economies as well as the growing power and influence of MNCs and TNCs. ${ }^{25}$ The US scholar Blumberg describes the impact of such MNC/MNEs (Multinational Enterprises) on global trade and business:

In the modern global economy, the largest corporations conduct worldwide operations. They operate in the form of multinational corporate groups organized in "incredibly complex" multi-tiered corporate structures consisting of a dominant parent corporation, sub holding companies, and

\footnotetext{
${ }^{21}$ This review is not meant to be a comprehensive analysis of the various norms listed in the document. For a comprehensive analysis of the various norms in the document, see Hillemanns, above n 9; Backer, above n 9; Deva, above n 13; Baxi, above n 20; Campagna, above n 13; Weissbrodt and Kruger, above n 9; Weissbrodt, above n 13.

${ }^{22}$ Weissbrodt, above n 13, 58.

${ }^{23}$ William H Meyer, 'Human Rights and MNCs: Theory versus Quantitative Analysis' (1996) 18 Human Rights Quarterly 368, 368-97.

${ }^{24}$ Weissbrodt, above n 13, 56-8.

${ }^{25}$ Kinley and Chambers, above n 9, 457.
} 
scores or hundreds of subservient subsidiaries scattered around the world. The 1999 World Investment Report estimated that there are almost 60,000 multinational corporate groups with more than 500,000 foreign subsidiaries and affiliates. $^{26}$

The UN Sub-Commission on the Promotion and Protection of Human Rights (hereinafter Sub-Commission) recognised the possibility of MNCs aiding and abetting human rights violations and hence being indirectly liable for them. It voiced 'significant concerns about the conduct of transnational corporations and other businesses'. ${ }^{27}$

Weissbrodt believed that international law in general, and international human rights law (IHRL) in particular, focused on protecting the individual from violations by governments, rather than from violations by other actors. Weissbrodt also thought that, while new groups of non-state actors are becoming subject to liability through the operation of various sub-fields of international law, TNCs and businesses in general remained largely unaffected by these developments. ${ }^{28}$ While some international legal documents may be interpreted as applying to corporations, most of them have applied to the TNCs only indirectly. ${ }^{29}$ However, such indirect regulation did

\footnotetext{
${ }^{26}$ Phillip I Blumberg, 'Asserting Human Rights against Multinational Corporations under United States Law: Conceptual and Procedural Problems' (2002) 50 The American Journal of Comparative Law 493, 493; Sascha-Dominik Bachmann, 'Human Rights and Global Business: The Evolving Notion of Corporate Civil Responsibility' [2009] Indian Yearbook of International Law and Policy 193, 193-220.

${ }^{27}$ Weissbrodt, above $\mathrm{n} 13,64$.

28 Such sub-fields of international law include the operation of the international criminal tribunals and the ICC (in which individuals can be held responsible for their actions), international humanitarian law (IHL) (under which armed opposition groups can be held responsible), and international criminal law (ICL) (under which terrorists and traffickers in human beings may be held responsible). See ibid 59-60; Permanent Mission of Canada to the Office of the United Nations in Geneva, 'Submission of Canada to the High Commissioner for Human Rights on the Responsibilities of Business Enterprises with Regard to Human Rights' (OHCHR 2004) [2.2], [3.3]-[3.4]; but see S R Ratner, 'Corporations and Human Rights: A Theory of Legal Responsibility’ (2001) 111 Yale Law Journal 443, 377-88.

${ }^{29}$ Among such documents one can recall the OECD Guidelines, ILO's Tripartite Declaration, the Convention on Combating Bribery, as well as the Warsaw Convention. Organization for Economic Co-Operation and Development, above n 12; International Labour Organization, above $\mathrm{n} \mathrm{12}$; International Convention on the Elimination of All Forms of Racial Discrimination, opened for signature 21 December 1965, GA 2106 (XX), UNTS vol. 660, 195 (entered into force 4 January 1969); Convention For the Unification of Certain Rules Relating to International Carriage by Air, opened for signature 12 October 1929, 137 LNTS 11 (entered into force 13 February 1933). See generally Vázquez, above n 18; but see David Kinley and Junko Tadaki, 'From Talk to Walk: The Emergence of Human Rights Responsibilities for Corporations at International Law' (2004) 44(4) Virginia Journal of International Law 931, 946-7.
} 
not prevent abuses of human rights by businesses and therefore several international efforts to create frameworks of direct obligations on TNCs were made. These attempts included the unsuccessful attempts to establish a UN Code of Conduct for Transnational Corporations, the OECD Guidelines for Multinational Enterprises, the ILO Tripartite Declaration of Principles Concerning Multinational Enterprises and the Global Compact initiative. ${ }^{30}$

The new Norms seemed at last to remedy the lack of accountability of corporations. Scholars were referring to the Norms, after their final drafting and their eventual disappearance from the agenda of the UN, as the 'most promising human rights norms for TNCs to date'. ${ }^{31}$ The German government described the Norms as a 'useful contribution to the ongoing debate on ways and means of integrating business enterprises in the international endeavours to promote and protect human rights and sustainable development'. ${ }^{32}$ The drafting initiative was supported by many NGOs. ${ }^{33}$ Furthermore, several transnational businesses, which participated in the 'Initiative for Respect' and the 'Ethical Globalisation Initiative', volunteered to participate in the 'pilot project' for the Norms, as part of their wider commitment to human rights. ${ }^{34}$

\footnotetext{
${ }^{30}$ UNCTC, above n 12, 231-43; International Labour Organization, above n 12; Organization for Economic Co-Operation and Development, above n 12; Weissbrodt and Kruger, above $\mathrm{n}$ 9, 903; Peter T Muchlinski, Multinational Enterprises and the Law (Oxford University Press, $2^{\text {nd }}$ ed, 2007) 474-6; Kinley and Chambers, above n 9, 455-6; Ratner, above n 28, 454-9; Ruggie, above n 6, 819; Campagna, above n 13, 1206-7; John Gerard Ruggie, 'Globalgovernance.net: The Global Compact as Learning Network' (2001) 7 Global Governance, 371, 371-8; John Gerard Ruggie, 'The Theory and Practice of Learning Networks: Corporate Social Responsibility and the Global Compact' (2002) 5 Journal of Corporate Citizenship 27, 27-36 ('United Nations Global Compact').

${ }^{31}$ See Deva, above n 13, 497; Campagna, above n 13; Hillemanns, above n 9, 1065; Weissbrodt and Kruger, above n 9; Weissbrodt, above n 13, 55.

${ }^{32}$ Permanent Mission of the Federal Republic of Germany to the Office of the United Nations and to the Other International Organizations in Geneva, 'German response to OHCHR notes verbale of 19 May 2004 and 22 July 2004 regarding CHR Decision 2004/116 Responsibilities of transactional corporations and related business enterprises with regard to human rights', Communication to the Office of the High Commissioner for Human Rights (29 September 2004) <http://www2.ohchr.org/english/issues/globalization/business/docs/ germany.pdf $>$.

${ }^{33}$ The list of NGOs supporting the initiative included Amnesty International, Human Rights Watch, Oxfam, and the Prince of Wales International Business Leaders Forum. See Weissbrodt and Kruger, above n 9, 906.

34 These businesses were: ABB, Barclays Bank, National Grid Transco, Novartis, Novo Nordisk, MTV and The Body Shop International, Gap Inc, Hewlett-Packard, Statoil; ibid 907; Kinley and Chambers, above n 9, 461; Weissbrodt, above n 13, 72-3.
} 
The Norms drew heavily from existing human rights documents ${ }^{35}$ and it seems that their overall aim was to fill a void in the existing frameworks of international law, by providing a single, comprehensive and constituting set of human rights norms with binding effect for all corporations. They were designed to serve as an accessible legal document which could be applied even by non-experts in international human rights law, particularly corporate directors. Deva further explained that the need to draft the Norms as a separate document, relying on other conventions and applying them to TNCs, was in fact evidence of the presence of certain gaps in the existing legal framework. ${ }^{36}$ On the other hand, one must question whether this need truly existed or whether the Norms were yet another redundant document. Campagna observed that the duty of TNCs to 'respect, protect and ensure human rights' worldwide, under the framework of the Norms, constituted a formal recognition of legal principles of international human rights law as evolved since World War II and particularly since the end of the Cold War. ${ }^{37}$

\section{DRAFTING HISTORY}

The Norms were not the first attempt to regulate the connection between business and human rights. ${ }^{38}$ They were preceded by a number of initiatives within the legal framework of the OECD and UN. ${ }^{39}$ However, these 'soft law' 'CSR' (Corporate Social Responsibility) styled initiatives did not seem to be sufficient to eliminate corporate abuses of human rights. In 1998 a Working Group on the Working Methods and Activities of Transnational Corporations was established by the UN Sub-Commission on Prevention of Discrimination and Protection of Minorities. ${ }^{40}$ It was mandated inter alia

\footnotetext{
${ }^{35}$ Many existing human rights documents are mentioned in the Preamble to the Norms, inter alia the Universal Declaration of Human Rights; Convention on the Prevention and Punishment of the Crime of Genocide; the Convention against Torture and Other Cruel, Inhuman or Degrading Treatment or Punishment; the Slavery Convention and the Supplementary Convention on the Abolition of Slavery, the Slave Trade, and Institutions and Practices Similar to Slavery; the International Convention on the Elimination of All Forms of Racial Discrimination; the Convention on the Elimination of All Forms of Discrimination against Women; the International Covenant on Economic, Social and Cultural Rights; the International Covenant on Civil and Political Rights. See the full list at Sub-Commission on the Promotion and Protection of Human Rights, above n 9, 3-7. See also Kinley and Chambers, above n 9, 451; Rule, above n 9, 333.

${ }^{36}$ Deva, above n 13, 499.

${ }^{37}$ Campagna, above n 13, 1222.

${ }^{38}$ Kinley and Chambers, aboven 9, 455.

${ }^{39}$ See above $\mathrm{n} 19$ and the accompanying text.

${ }^{40}$ Ragnwaldh and Konopik, above n 7, 251-2.
} 
to make recommendations and proposals relating to the methods of work and activities of transnational corporations in order to ensure that such methods and activities are in keeping with the economic and social objectives of the countries in which they operate, and to promote the enjoyment of economic, social and cultural rights and the right to development, as well as of civil and political rights. ${ }^{41}$

The Working Group drew from prior work which was based on three background reports. ${ }^{42}$ The first report of 1995 emphasised the gradual shift of power from states to TNCs, noting the adverse effect of the global strategies of TNCs on the promotion of human rights, and particularly international labour and trade union rights. ${ }^{43}$ A second report of 1996 focused on the

41 Sub-Commission on Prevention of Discrimination and Protection of Minorities, 'The Relationship Between the Enjoyment of Economic, Social and Cultural Rights and the Right to Development, and the Working Methods and Activities of Transnational Corporations', above $n$ 8, 4(d). During the subsequent years, the mandate of the Working Group was expanded several times. When the mandate was further extended in 2001, the SubCommission's Resolution 2001/3 provided more detail on the expected outcome of the Working Group in paragraph 4. '(b) Compile a list of the various relevant instruments and norms concerning human rights and international cooperation that are applicable to transnational corporations; (c) Contribute to the drafting of relevant norms concerning human rights and transnational corporations and other economic units whose activities have an impact on human rights; (d) Analyse the possibility of establishing a monitoring mechanism in order to apply sanctions and obtain compensation for infringements committed and damage caused by transnational corporations, and contribute to the drafting of binding norms for that purpose;' Sub-Commission on Human Rights, above n 8; Weissbrodt and Kruger, above n 9, 904-5; Kinley and Chambers, above n 9, 463.

${ }^{42}$ Backer, above n 9, 322; Sub-Commission on the Promotion and Protection of Human Rights, above n 8; Sub-Commission on Prevention of Discrimination and Protection of Minorities, The Relationship between the Enjoyment of Human Rights, in Particular, International Labour and Trade Union Rights, and the Working Methods and Activities of Transnational Corporations, $47^{\text {th }}$ sess, Agenda Item 8, UN Doc E/CN.4/Sub.2/1995/11 (24 July 1995); SubCommission on Prevention of Discrimination and Protection of Minorities, The Impact of the Activities and Working Methods of Transnational Corporations on the Full Enjoyment of All Human Rights, in Particular Economic, Social and Cultural Rights and the Right to Development, Bearing in Mind Existing International Guidelines, Rules and Standards Relating to the Subject-Matter, $48^{\text {th }}$ sess, Agenda Item 8, UN Doc E/CN.4/Sub.2/1996/12 (2 July 19996); Sub-Commission on Prevention of Discrimination and Protection of Minorities, Working Document on the Impact of the Activities of Transnational Corporations on the Realization of Economic, Social and Cultural Rights, Prepared by Mr. El Hadji Guissé, Pursuant to Sub-Commission Resolution 1997/11, UN ESCOR $50^{\text {th }}$ sess, UN Doc E/CN.4/Sub.2/1998/6 (10 June 1998).

43 Sub-Commission on Prevention of Discrimination and Protection of Minorities, 'The Relationship Between the Enjoyment of Human Rights, in Particular, International Labour and Trade Union Rights, and the Working Methods and Activities of Transnational Corporations' above n 42; Backer further argues that the report goes further and essentially defines the state as 'any amalgamation of power that can assert the power normally exercised by, or otherwise coerce entities that are recognized as states'. In accordance with this analysis, 
possibilities of subjecting a corporation as a whole to a single jurisdiction. ${ }^{44}$ Of particular importance was the third report by El-Hadji Guissé in 1998. According to Backer, El-Hadji Guissé's work with and through the Working Group provided the legal foundations and perspectives for what eventually became the Norms.

The report presented as a thesis that TNCs were 'vehicles' in the transfer of wealth away from the poor to the rich, which in fact represented a market failure in need of fundamental correction. The report claimed that while the raison d'etre of the TNCs was to make profit, they also had to comply with the system of values on which our existence is based. Therefore the report emphasised the importance of regulating and restraining the actions of TNCs through national regulation and international cooperation of states. ${ }^{45}$ It is submitted, however, that, unlike the Norms that followed and deviated from the other two background reports, Guissé's report concerned solely the responsibilities and duties of states to regulate the conduct of TNCs, rather than establishing direct responsibilities for TNCs themselves. ${ }^{46}$

The process of discussion and drafting was lengthy, with the mandate of the Working Group being renewed and altered several times. ${ }^{47}$ The Working Group began preparing the Norms in August 1999. It held annual public hearings, attended by selected representatives from business, the unions, NGOs, the scholarly community and other interested persons and met in Geneva between 2000 and 2003. The various drafts were also published on the internet and in the UN publications. ${ }^{48}$

The final detailed document and its commentary were introduced and approved in August 2003 by the Sub-Commission. The Sub-Commission sent

the TNCs are to be treated as being on a level similar to states and should therefore have some of the responsibilities according to their role: Backer, above n 9, 322-3.

${ }^{44}$ Sub-Commission on Prevention of Discrimination and Protection of Minorities, 'The Impact of the Activities and Working Methods of Transnational Corporations on the Full Enjoyment of All Human Rights, in Particular Economic, Social and Cultural Rights and the Right to Development, Bearing in Mind Existing International Guidelines, Rules and Standards Relating to the Subject-Matter' above n 42, 22; Backer, above n 9, 325-6.

${ }^{45}$ Sub-Commission on Prevention of Discrimination and Protection of Minorities, above n 42, [13], [24]-[5]; Backer, above n 9, 326-7.

${ }^{46}$ On the direct linkage between international law and TNCs in the Norms. See Backer, above $\mathrm{n}$ 9, 374-5.

${ }^{47}$ Weissbrodt and Kruger, above n 9, 903-5; Sub-Commission on Prevention of Discrimination and Protection of Minorities, above $\mathrm{n} 8$; Sub-Commission on the Promotion and Protection of Human Rights, above $\mathrm{n} 8$.

${ }^{48}$ Weissbrodt, above n 13, 67-8; Hillemanns, above n 9, 1069-70. 
the Norms to its parent body, the former UN Commission on Human Rights. On 22 April 2004, by an 'action without a vote', a consensual decision, the UN Commission on Human Rights significantly narrowed the original objectives and methodologies of the Norms. It recommended that ECOSOC should confirm the importance of the question of the responsibilities of transnational corporations with regard to human rights. It also requested that the new Office of the High Commissioner for Human Rights (OHCHR) compile a report setting out the scope and legal status of current initiatives and standards relating to the responsibility of transnational corporations. The report affirmed that the Norms had no legal standing, had not been requested by the Commission and that the Sub-Commission would not perform any monitoring function in relation to the Norms. ${ }^{49}$ The Commission disseminated the document for further comment, as was recommended by the SubCommission, and received over 90 comments in six months. The 2004 session of the Commission welcomed the Norms, yet, in light of the widespread criticism from various states and the business community ${ }^{50}$ noted that it had not actually asked for such a document and that, as a draft before the Commission, the document did not have any legal status on its own. ${ }^{51}$

\section{Progressive Development, Novelties AND SHORTFALLS OF THE NORMS}

The Norms were, in many ways, setting new legal standards regarding corporate human rights responsibilities. Although reflecting and drawing from already existing human rights obligations, the Norms incorporated notions of progressive development and novel conceptions of human rights protection. The Norms attempted to establish direct responsibility of TNCs for human rights violations, utilising existing frameworks of international law. They aimed to establish an explicit duty for TNCs to promote human rights from 'top to bottom', even in respect of corporations registered in non-state parties. These norms were designed to constitute a 'non-voluntary' framework, which was far more codified than any voluntary framework, but which fell short of

\footnotetext{
${ }^{49}$ Backer, above n 9, 331.

${ }^{50}$ See the discussion on the criticism of the Norms in Part 5 below.

${ }^{51}$ Kinley and Chambers, above n 9, 451, 463; Weissbrodt, above n 13, 64-8; Baxi, above n 20, 2; One should note, however, that although the Commission was correct that it did not ask for this document, the Sub-Commission had full powers to ask for its drafting as it did. See the Resolutions of the Sub-Commission defining the Mandate of the Working Group: SubCommission on Prevention of Discrimination and Protection of Minorities, above $n$ 8; SubCommission on the Promotion and Protection of Human Rights, above $n 8$.
} 
being mandatory, constituting 'soft law' instead of 'hard law'. This Part will discuss these novelties and contradictions.

The Preamble of the Norms essentially reiterated the fundamental character of Corporate Social Responsibility as a means to promote and protect human rights. ${ }^{52}$ The Norms were basically a furtherance of human rights principles already set down in the Universal Declaration on Human Rights (UDHR) of $1948 .^{53}$ Campagna thought that the legal foundations of the duty of TNCs to promote and protect human rights, as defined in the Norms, derived directly from the UDHR. ${ }^{54}$ As part of the attempt to characterise the Norms as a mere codification of already established principles of customary international law, rather than a progressive development of such legal principles, the Preamble contained an open, non-exhaustive list of the international treaties and conventions which established the legal basis for TNCs' obligations in the area of human rights. Some of them arguably even reached the level of jus cogens. ${ }^{55}$ In Baxi's view, this raised the problem of intelligibility, as not everyone among those affected by corporate violations of human rights - nor among the CEOs in the business community — is familiar with the full range of human rights instruments referred to in the Norms. ${ }^{56}$ Consequently, the

\footnotetext{
${ }^{52}$ Backer, above n 9, 341 .

${ }^{53}$ Hillemanns, above n 9, 1072; Sub-Commission on the Promotion and Protection of Human Rights, above n 9, Preamble.

${ }^{54}$ Campagna, above n 13, 1208; See also Louis Henkin, 'The Universal Declaration at 50 and the Challenge of Global Markets' (1999) 25 Brooklyn Journal of International Law 17, 24-5 presenting the thesis upon which to build the obligations of the corporations to the UDHR. Universal Declaration of Human Rights, GA Res 217 A (III), UN GAOR, $3^{\text {rd }}$ sess, $183^{\text {rd }}$ plen mtg, UN Doc A/810 (10 December 1948) Preamble; see also the response of Germany to the Norms, claiming that the UDHR does apply direct obligations on TNCs: Permanent Mission of the Federal Republic of Germany to the Office of the United Nations and to the Other International Organizations in Geneva, above n 32. It is, however, questionable whether the UDHR is part of customary international law. See Hurst Hannum, 'The Status of the Universal Declaration of Human Rights in National and International Law' (1996) 25 Georgia Journal of International and Comparative Law 287, 322-35; Campagna, above n 13, 1209; and whether the application of UDHR norms to non-state actors is not an overstretching thereof. See Deva, above n 13, 498; but see Filartiga v Pena-Irala 630 F.2d 876 (2d Cir. 1980); Andrew Clapham and Scott Jerbi, 'Categories of Corporate Complicity in Human Rights Abuses' (2001) 24 Hastings International and Comparative Law Review 339, 340-1.

${ }^{55}$ Baxi, above n 20, 3 claims that these references to prior textual enunciations are very characteristic of soft law documents and represent a process of 'self-generating normative cannibalism, or self-devouring conspicuous consumption'. This reliance on what the drafters of the Norms believed to be established principles of international law, allowed them to ground their presentation of the Norms as a restatement of existing international law: SubCommission on the Promotion and Protection of Human Rights, above n 9, Preamble; Deva, above n $13,498$.

${ }^{56}$ As one may recall, the text of the Norms refers to at least 56 previous human rights instruments: Baxi, above n 20, 3-6; but see Rule, above n 9, 330 who claims that one of the
} 
Preamble of the Norms not only served as an introduction to the main document, but also explained the core substance of the Norms. ${ }^{57}$

The operative part of the Norms was divided into seven main categories. It presented a comprehensive list of human rights obligations relevant to TNCs. The Norms did not set down so called 'negative' duties ${ }^{58}$ (whereby TNCs should refrain from violating human rights), but rather introduced as a 'positive' duty for TNCs the obligation to promote and ensure respect for human rights. ${ }^{59}$ It thus supplemented the traditional, horizontal scale of state 'sponsored' human rights protection.

Under 'General Obligations' in Part A of the Norms were listed the following responsibilities: the duty of due diligence to ensure that business activities do not directly or indirectly contribute to human rights abuses; the duty to ensure that corporations do not benefit from such abuses; the duty to refrain from undermining efforts to promote human rights; the duty of a corporation to use its influence to promote human rights; the obligation to assess the human rights impact of the corporation; and the overall responsibility to avoid complicity in human rights abuses. ${ }^{60}$

These obligations are significant and affected the entire document. ${ }^{61}$ Article 1 recognised states as the traditional holders of the primary responsibilities

advantages of the Norms, is the fact that they present in a single document, the entire array of human rights applicable to TNCs.

${ }^{57}$ Backer, above $\mathrm{n} 9,342-3$ substantiates his claim that the Preamble is part of the substantive obligations of the Norms based on the fact that the Norms are to be elaborated and interpreted according to the Preamble. However, this characterises the role of every Preamble according to the Vienna Convention on the Law of Treaties, and therefore contradicts Backer's claim, as the role of the Preamble is specifically designed to differ from the role of the substantive part. See Vienna Convention on the Law of Treaties, signed 23 May 1969, 1155 UNTS 331 (entered into force 27 January 1980) art 31.

${ }^{58}$ Negative duties are the duties to refrain from doing something, ie 'not to obstruct the right to demonstrations'; while positive duties are duties to do something actively, ie 'to provide free education'. See, eg, Philip Alston and Gerard Quinn, 'The Nature and Scope of States Parties' Obligations under the International Covenant on Economic, Social and Cultural Rights' (1987) 9 Human Rights Quarterly 156, 184.

${ }^{59}$ Deva, above n 13, 497-9.

${ }^{60}$ Sub-Commission on the Promotion and Protection of Human Rights, above n 9, General Obligations.

${ }^{61}$ Sub-Commission on the Promotion and Protection of Human Rights, Commentary on the Norms on the Responsibilities of Transnational Corporations and Other Business Enterprises with Regard to Human Rights, UN ESCOR 55th sess 22nd mtg Agenda Item 4, UN Doc E/CN.4/Sub.2/2003/38/Rev.2 (26 August 2003) art 1(a); Deva, above n 13, 502. 
to promote, secure the fulfilment of, respect, ensure respect of and protect human rights recognized in international as well as national law, including ensuring that transnational corporations and other business enterprises respect human rights. ${ }^{62}$

The Norms' overall impact, however, would have been more radical than Article 1 suggests: they essentially relegated states to the background in the attempt to protect human rights in the transnational business context. TNCs would have been forced to operate against the interests of a state in order to comply with the 'greater, internationally-derived good' of transnational human rights compliance. ${ }^{63}$

The primacy of the role given to corporations, and its lack of definition in the Norms led to significant reservations being expressed against such perceived - 'demotion' of states. Baxi argued that there are several possible interpretations of the term 'primary responsibility' which would significantly influence the scope of the role of the states and their obligations according to the Norms. ${ }^{64}$ The United States Council for International Business criticised the Norms for the fact that they 'represent a fundamental shift in responsibility for protecting human rights - from governments to private actors, including companies - effectively privatizing the enforcement of human rights laws'. ${ }^{65}$ This critique was aimed at the very nature of the Norms. They were intended to improve human rights protection in cases where states failed to act, thereby widening the scope of applicability of international human rights law by including situations where corporations have de facto greater influence than that of the states ${ }^{66}$

\footnotetext{
${ }^{62}$ Sub-Commission on the Promotion and Protection of Human Rights, above n 9, art 1; Weissbrodt, above n 13, 64-5.

${ }^{63}$ Backer, above n 9, 373 .

${ }^{64}$ Even if one claims that the explanation for the lack of commentary on this term relates to the fact that the Norms are focusing on TNCs, one can still understand the role of the states as either active or passive. Baxi, above n 20, 9-10.

65 Vázquez, above n 18, 929; Timothy E Deal, 'The Human Rights Responsibilities of International Business' (Paper presented at the Frank Hawkins Kenan Institute of Private Enterprise Seminar, 'Are Human Rights the Business of Business?', United States Council for International Business, Washington DC, 10 December 2003).

${ }^{66}$ Kinley and Chambers, above n 9, 465-72; Facsimile Message from Australian Permanent Mission to the UN to OHCHR, 8 September 2004, 'Comments by Australia in Respect of the Report Requested from the Office of the High Commissioner for Human Rights by the Commission on Human Rights in its Decision 2004/116 of 20 April 2004 on Existing Initiatives and Standards Relating to the Responsibility of Transnational Corporations and Related Business Enterprises With Regard to Human Rights' <http://www2.ohchr.org/ english/issues/globalization/business/docs/australia.pdf $>$.
} 
Within their respective spheres of activity and influence, transnational corporations and other business enterprises have the obligation to promote, secure the fulfilment of, respect, ensure respect of and protect human rights recognized in international as well as national law, including the rights and interests of indigenous peoples and other vulnerable groups. ${ }^{67}$

The 'Commentary on the Norms on the Responsibilities of Transnational Corporations and Other Business Enterprises with Regard to Human Rights' clarified that the Norms should apply regardless of the state in which TNCs operated, and what the level of human rights protection in the respective state was. $^{68}$

The Norms laid down, as specific rules and obligations for corporations, the duty to protect the right to equal opportunity and non-discriminatory treatment, the right to security of persons, labour rights of workers, the right of fair remuneration, the respect for national sovereignty and human rights, obligations relating to consumer protection (which were uniquely designed for TNCs) and, finally, obligations with regard to environmental protection. ${ }^{69}$

Of particular interest is Part E of the Norms, in which TNCs were identified as possible multipliers for the development of a global business society bound to the rule of law, transparency, accountability and sustainable development, and in which the peoples' civil, political, economic and cultural rights were realised. This was an innovation in three main respects. Firstly, instead of limiting TNCs' obligations to civil and political rights only, the Norms included both civil rights and collective social, economic and cultural rights of the second and third generations of human rights. Secondly, as mentioned above, this imposed positive obligations upon TNCs, which in effect created a 'quasi' horizontal structure of human rights protection. Thirdly, TNCs were expected to respect and promote even the rights of those individuals who were affected only indirectly by their activities. ${ }^{70}$

Part $\mathrm{H}$ dealt with the general provisions concerning implementation of the Norms. ${ }^{71}$ Deva distinguished between direct and indirect aspects of

\footnotetext{
${ }^{67}$ Sub-Commission on the Promotion and Protection of Human Rights, above n 9, Part A art 1; Campagna, above n 13, 1225.

${ }^{68}$ Sub-Commission on the Promotion and Protection of Human Rights, above n 61, art 1(a); Deva, above n 13, 502.

${ }^{69}$ Sub-Commission on the Promotion and Protection of Human Rights, above n 9, B-G. These rules are explained and explicated in great detail in the Commentary attached to the Norms. Sub-Commission on the Promotion and Protecton of Human Rights, above $\mathrm{n} 61$.

${ }^{70}$ Deva, above n 13, 507; Vázquez, above n 18, 945; see also Ratner, above n 28, 499-500.

${ }^{71}$ Sub-Commission on the Promotion and Protection of Human Rights, above n 9, H.
} 
implementation of the Norms as defined there. TNCs were expected to both internalise the culture of the Norms, as well as being subjected to periodic monitoring and verification by different bodies. Indirectly, the Norms were to be promoted through amendment by the states of their national legal frameworks, which would ensure that TNCs implemented the Norms. ${ }^{72}$ Backer claimed that, through the general provisions, the Norms exploited the flexibility of private lawmaking to maximise the efficiency of implementation, without the interference of state actors. ${ }^{73}$

The final part of the Norms, Part I provided various definitions required for the interpretation of the Norms. ${ }^{74}$ Of particular importance was the definition of the term 'transnational corporation', which was kept deliberately broad and referred to an 'economic entity operating in more than one country or a cluster of economic entities operating in two or more countries - whatever their legal form, whether in their home country or country of activity, and whether taken individually or collectively'. This definition was to be read in conjunction with the definition of 'other business entities', which was drawn up to 'ensure that transnational corporations could not change their identity ... and therefore avoid the draft Norms', and potentially included nearly all existent business entities to date. ${ }^{75}$ The terms 'human rights' and 'international human rights' were also defined widely for the purposes of the Norms. The terms included

civil, cultural, economic, political and social rights, as set forth in the International Bill of Human Rights and other human rights treaties, as well as the right to development and rights recognized by international humanitarian law, international refugee law, international labour law, and other relevant instruments adopted within the United Nations system. ${ }^{76}$

This definition allowed the inclusion of human rights norms and standards of different levels and generations. While some of the norms listed in the document had universal legal effect, others were norms of positive character existent only between parties to certain agreements. Some were even norms with no general legal effect and as such of nonbinding 'soft law' effect. ${ }^{77}$

\footnotetext{
${ }^{72}$ Deva, above n 13, 514-18.

${ }^{73}$ Backer, above n 9, 334 .

${ }^{74}$ Sub-Commision on the Promotion and Protection of Human Rights, above $\mathrm{n} 9$, I.

${ }^{75}$ Ibid 20-1; Backer, above n 9, 337.

${ }^{76}$ Sub-Commission on the Promotion and Protection of Human Rights, above n 9, 23.

${ }^{77}$ Backer, above n 9, 340 .
} 
It seems that a discrepancy existed between the major issues discussed while drafting the Norms and the issues which were the basis for the later criticism of the Norms. There were five main features of the norms which were widely discussed during the drafting process.

The first was the scope of application of the Norms and the decision to define the term 'transnational corporations' to include all types of business entities. Weissbrodt emphasised that, while most media attention focused on the misdeeds of major corporations, applying human rights standards only to large TNCs could have been considered discriminatory. Moreover, the drafters considered it difficult to define the term TNC in such a way as not to allow corporate lawyers to restructure the corporation in a way that would prevent these standards being applied to this corporation. ${ }^{78}$

Secondly, because the drafters of the Norms believed that the principles should be respected by all businesses, and in order to avoid distinctions between the standards applied to domestic and transnational corporations, they applied the Norms to all corporations, while minimizing the need for implementation of the rules by small 'mom and pop' shops. ${ }^{79}$

Thirdly, the drafters of the Norms decided on an approach according to which the power and the influence of a corporation should be matched by the appropriate level of responsibility. ${ }^{80}$

Fourthly, the Norms were designed to constitute the most comprehensive and human rights-focused document applying transnational rules to businesses up to that time. ${ }^{81}$

Finally, the Norms were designed to have a special non-voluntary character. While the Norms did not amount to an 'international treaty', according to their drafters, the drafters described the Norms as a 'soft-law' restatement of the principles applicable to corporations. Such principles were derived from international treaties and customary international law. ${ }^{82}$

\footnotetext{
${ }^{78}$ Weissbrodt, above n 13, 65-6; see also Baxi, above n 20, 6-9.

${ }^{79}$ Deva, above n 13, 500-1; Weissbrodt and Kruger, above n 9, 907-12.

${ }^{80}$ This approach is in line with the theory of legal responsibility of corporations suggested by Ratner: Ratner, above $\mathrm{n} 28$.

${ }^{81}$ Furthermore, one of the much disputed additions to the Norms was their encouragement of further evolution of the existing and similar human rights standards: Weissbrodt, above $\mathrm{n} 13$, 66-7.

${ }^{82}$ Weissbrodt and Kruger, above n 9, 907-15; Deva, above n 13, 513; Weissbrodt, above n 13, 67.
} 
Another novelty of the Norms was their use of a binding 'shall' language, instead of the previously accepted 'should' terminology. ${ }^{83}$

Out of the issues mentioned above, only the all-inclusive and the nonvoluntary character of the Norms were mentioned by the opponents of the Norms. The criticism of the Norms was focused mostly on 1) the transition of responsibility from states to $\mathrm{TNCs}$ and the associated alteration of the traditional framework of international law; 2) the imposition on TNCs of responsibility for the actions of other actors; and 3) the perceived excessive legalism of the document on the one hand and its vagueness on the other.

The Norms related to TNCs as entities with distinct social, cultural, civil and political rights and duties. The Norms did not treat TNCs only as legal entities whose function is limited to the economic sphere and whose activities must be regulated in order for the entity to remain active in this sphere. Backer asserted that the Norms treated corporations as 'virtual State actors' for the purposes of many normative requirements. ${ }^{84}$ They bypassed the medium of the state, in order to create a direct link between international law and TNCs. In doing so they made the TNCs important actors in promoting human rights, mainly in the developing countries, but also in the developed countries that refused to adopt certain human rights norms. ${ }^{85}$

Several aspects of the Norms are worthy of a deeper analysis. The Norms drew from previous human rights instruments the obligations relevant to TNCs and other business entities and applied them directly to the corporations. At the same time they reemphasised the primary and the overarching responsibility of the states. ${ }^{86}$ Kinley and Chambers identified four points where the Norms diverged from traditional human rights documents.

\footnotetext{
${ }^{83}$ Deva, above n 13, 499-500; Deal, above n 65; Professor Emeritus Maurice Mendelson QC, 'In the Matter of the Draft 'Norms on the Responsibilities of Transnational Corporations and Other Business Enterprises with Regard to Human Rights' (Opinion Piece, OHCHR, 4 April 2004) [5]. This fact is inconsistent with the general normative language of the document. Rule links this with the previous failures to promote human rights laws enforced by the UN, and a desire to stimulate or accelerate desired changes in societal norms in order to accelerate accordingly the pace of corresponding changes in the law: Rule, above n 9, 332 .

${ }^{84}$ Backer, above n 9, 371. Moreover, through this the Norms seem to contradict the obligation to respect national sovereignty as defined in article 10 of the Norms.

85 One example is that of the United States, which continuously refused to ratify the International Covenant on Economic, Social and Cultural Rights. Nevertheless, through the Norms, the TNCs therein would become bound by that instrument: ibid 353, 371-2.

${ }^{86}$ Rule, above n 9, 333.
} 
Firstly, unlike other human rights instruments, the Norms revolved around the duty-bearers, to which the different rules apply, rather than focusing on a single set of rights (civil, political, and economic) or rights holders (women, children, racial groups). ${ }^{87}$ The focus of the Norms on duty-bearers, rather than on a specific set of rights also caused them to be indeterminate about the exact scope of the specific rights, applicable to the TNCs. ${ }^{88}$

Secondly, the notion of a 'sphere of influence', and thus responsibility, derived from the corporate social responsibility (CSR) movement. This aspect of the Norms has also been criticised for not being clear enough, and being ambiguous about the question of whether the entire supply chain of the corporation lies within its 'sphere of activity and influence'.

Thirdly, the Norms sought to establish new enforcement mechanisms applicable to non-state actors, and to make non-state actors the promoters of these norms and mechanisms when entering into contractual relationships with their business partners. ${ }^{90}$ The subject of enforcement was a key issue addressed by the Norms. ${ }^{91}$ TNCs were to be subject to 'periodic monitoring and verification by United Nations and other international and national mechanisms already in existence or yet to be created regarding the application of the Norms. ${ }^{92}$ Vázquez further claimed that states would be reluctant to create and maintain institutions, established under the Norms, as this would limit their own sovereign powers. ${ }^{93}$ Furthermore, he suggested that legal norms were less likely to be observed by non-state actors in the absence of effective enforcement mechanisms carrying sanctions. ${ }^{94}$ Another alleged shortcoming of this mechanism was its unintended anti-democratic character: an allegation based on the fact that the Norms had been drafted by subject matter experts and were not subject to further scrutiny by the (affected) states.

\footnotetext{
${ }^{87}$ Kinley and Chambers, above n 9, 452.

${ }^{88}$ The Norms are, therefore, ambiguous on whether the same scope of positive obligations applies to TNCs as it does to states. See Deva, above n 13, 510-511.

${ }^{89}$ Kinley and Chambers, above n 9, 452; Deva, above n 13, 502-3; Baxi, above n 20, 11-14.

${ }^{90}$ Kinley and Chambers, above n 9, 452-3; Baxi, above n 20, 18.

${ }^{91}$ Weissbrodt, above n 13, 67; Backer, above n 9, 384.

92 Sub-Commission on the Promotion and Protection of Human Rights, above n 9, art 16; Campagna, above $\mathrm{n}$ 13, 1247.

${ }^{93}$ His claim in fact matched the views of various States. See, eg, the Australian and Norwegian responses to the Norms that argues exactly that. Australian Permanent Mission to the UN, above n 66; Norwegian Ministry of Foreign Affairs, 'Decision 2004/116 - Responsibilities of Transnational Corporations and Related Business Enterprises with Regard to Human Rights', Communication to the Office of the High Commissioner for Human Rights, 4 November $2004<$ http://www2.ohchr.org/english/issues/globalization/business/docs/norway.pdf $>$.

${ }^{94}$ Vázquez, above n 18, 954-55.
} 
This outcome could have been the result of the influence of NGOs on the drafting process. ${ }^{95}$ Yet another perceived shortfall of this mechanism was its supposed lack of enforcement available in case of violations. ${ }^{96}$ However, this shortcoming was only alleged. In fact, there was a rigid enforcement mechanism which obligated the TNCs to have business relations only with TNCs that adhered to the Norms. Another element of implementation was the duty of the TNCs to provide 'prompt, effective and adequate reparations to those persons, entities and communities' that had been adversely affected by failure to comply with the Norms. ${ }^{97}$

Fourthly, the Norms added to the traditional list of human rights and fundamental freedoms other rights associated with consumer protection, the environment and issues of corruption. ${ }^{98}$ Kinley and Chambers observed that this development was sensible as violations of the dominant norms in these areas may lead to violations of other, more basic human rights, such as the right to life ${ }^{99}$ and may deny populations their economic, social and cultural rights ${ }^{100}$ and other basic and widely accepted rights such as the right to health and the right to development. ${ }^{101}$

One of the advantages of the Norms was the range of their possible impact. By virtue of their non-voluntary nature they had, as an instrument of regulation, the potential to overcome the so-called 'free-rider' dilemma of many TNCs. By contrast, the adoption by TNCs of voluntary programmes for the protection of human rights would disadvantage them economically against their competitors in the market, who did not take similar actions. ${ }^{102}$ Backer also argued that the support for the Norms by both important sectors of civil society and by the international law establishment was evidence for the evolving of transnational law, an evolution which has produced 'a mechanics

\footnotetext{
${ }^{95}$ Backer also notes that the enforcement mechanism of the Norms would have as a side effect an increase in the power of other non-state actors - namely NGOs which were supposed to have an active role in the enforcement mechanism. Backer, above n 9, 384-8.

${ }^{96}$ Campagna, above n 13, 1247; Deva, above n 13, 518-19.

${ }^{97}$ See Sub-Commission on the Promotion and Protection of Human Rights, above $\mathrm{n}$ 9, art 1516; Deva, above n 13, 500.

${ }^{98}$ Kinley and Chambers, above n 9, 453-5; Vázquez, above n 18, 944-7; Baxi, above n 20, 16 17; Deal, above n 65.

${ }^{99}$ Which may be the result of serious violations of consumer protection.

${ }^{100}$ Which may be the result of squandering national resources for the benefit of a privileged few in the absence of proper anti-corruption norms.

${ }^{101}$ Kinley and Chambers, above n 9, 472-4.

102 Campagna, above n 13, 1223; but see Vázquez claiming that the Norms emphasise the problem of 'free riding' for non-state actors, and may therefore, through the constant violations of these norms, bring about their demise: Vázquez, above n 18, 955-57.
} 
of interplay between national, international, public, and private law systems in allocating and competing for regulatory power'. ${ }^{103}$

\section{THE NORMS - AN APPRAISAL}

This Part analyses the responses to the Norms through examining the validity of and reasons for these responses.

Backer identified and analysed the two main types of response to the Norms. The 'public sector oriented' participants, a term which mainly refers to academics and NGOs, supported this instrument for being an advance over existing voluntary standards by providing a single comprehensive regime which drew an appropriate balance between the obligations of states and those of companies with respect to human rights. They claimed that the Norms provided also a template for state compliance with human rights along with a system of restorative remedies for individuals supervised by a supra-national organisation. The second group, 'private sector' or 'market oriented' participants, emphasised the extreme radicalism of the Norms - the mandatory approach; the presumption that private economic entities were more, rather than less, likely to promote human rights and development; the lack of a legal basis for imposing obligations on TNCs under international law, particularly in light of the vagueness and questionable legal effect of some of the norms mentioned in the document. ${ }^{104}$ The second group was the more influential one, and it was the one that eventually determined the future of the Norms.

We shall first examine the responses of the business sector. Despite the fact that the majority in the business community - mainly the business chambers and industry organisations - rejected the Norms, some favoured the application of the Norms and even volunteered as test participants in an implementation of the Norms. On the other hand, parts of the business community claimed that compliance with human rights law should be by choice and should occur only to the extent needed by the business community. They also argued that nation states, rather than the UN, should enforce human rights. ${ }^{105}$ The International Chamber of Commerce and the International Organisation of Employers issued a joint statement opposing the Norms and their 'legalistic approach'. At the same time the US Council for International

\footnotetext{
${ }^{103}$ Backer, above n 9, 288.

${ }^{104}$ Ibid 356-7; Norwegian Ministry of Foreign Affairs, above n 93.

105 This view was supported by some of the states that opposed the Norms, claiming that the states should be the primary obligor under the Norms. Backer, above n 9, 344 .
} 
Business opposed the Norms through criticising their vagueness. Senior Vice President Deal, claimed that the Norms created a 'legal no man's land'. ${ }^{106} \mathrm{He}$ argued that because the document did not distinguish between binding and non-binding human rights obligations (since some of its principles were drawn from non-binding human rights instruments) it blurred the line between voluntary and mandatory corporate compliance, thus making 'corporate compliance virtually impossible'. ${ }^{107}$ Kinley and Chambers argued, however, that a certain level of vagueness was not only expected from an international document (as opposed to domestic legislation), but was actually required in order to create consensus on the international level. ${ }^{108}$

Under the Norms, the duties of the TNCs were to increase not just directly, but indirectly as well. Not only might the Norms have placed a legal liability upon a corporation which colluded with a state in the commission of human rights violations, but they also stipulated the duty of a TNC to 'impose' human rights obligations upon states, even if these states refused to ratify the human rights instruments involved. ${ }^{109}$ Backer claimed that this reflected the use of mechanisms of so called 'low level' international governance, meaning international governance that arises 'at the level of private law in the municipal systems of sovereign states', which has been a contested issue in the field of international relations. ${ }^{110}$ As Deva observed, the Norms were probably too focused on stressing the importance of the universality of human rights, while ignoring both operational standards and the realities of human rights protection in the context of corporate business realities, and regional and cultural differences. ${ }^{111}$

Perhaps, the best characterisation of the approach adopted by the Norms was reflected in the eleventh paragraph of its Preamble:

Noting that transnational corporations and other business enterprises have the capacity to foster economic well-being, development, technological improvement and wealth as well as the capacity to cause harmful impacts on the human rights and lives of individuals through their core business practices and operations, including employment practices, environmental

\footnotetext{
106 The extreme criticism of the Norms by these bodies is of particular interest, in light of the fact that they were invited to participate and did participate to some extent, in the drafting process of the Norms. Weissbrodt, above n 13, 70.

${ }^{107}$ Campagna, above n 13, 1205-8; Vázquez, above n 18, 929; Deal, above n 65.

${ }^{108}$ Kinley and Chambers, above n 9, 466-7.

${ }^{109}$ Backer, above n 9, 371-80; Ruggie, above n 6, 825-6; Kinley and Chambers, above n 9, 452, 468-72.

${ }^{110}$ Backer, above n 9, 334 .

${ }^{111}$ Deva, above n 13, 511-13.
} 
policies, relationships with suppliers and consumers, interactions with Governments and other activities ... ${ }^{112}$

According to some commentators, the second part of this paragraph and the extended scope of responsibility of TNCs for the activities of other participants in the business chain, such as suppliers, partners, joint ventures and even governments, was one of the most problematic aspects of the Norms. ${ }^{113}$ The business community criticised the Norms and referred to the benefits of corporate business activities in terms of economic growth and stability as well as its own commitment to voluntary self regulation in the few cases where human rights violations were happening. John Cridland, Deputy Director-General of the Confederation of British Industries (CBI) was quoted to have said, '[t]hat leaves business having to blow the whistle on something that aims to subject firms to criticism and liability for abusing human rights. It is quite wrong to suggest that firms are generally involved in widespread abuse of human rights - where is the evidence?' 114

Another major concern for many corporations was the matter of reparations that the companies would be liable to pay, in accordance with the Norms. ${ }^{115}$

${ }^{112}$ Sub-Commission on the Promotion and Protection of Human Rights, above $n$ 9, Preamble [11].

${ }^{113}$ Kinley and Chambers, above n 9, 448-9; Baxi, above n 20, 8-9.

${ }^{114}$ Kinley and Chambers, above n 9, 448-9; see also the Facsimile Message from the United States Mission to International Orgnisations to Mr Dzidek Kedzia, OHCHR, 30 September 2004, RE Note Verbale from the OHCHR of August 3, 2004 (GVA 2537) <http://www2. ohchr.org/english/issues/globalization/business/docs/us.pdf $>$.

115 The problem of individuals acquiring reparations for human rights abuses from corporations is particularly difficult when there is no effective possibility of remedies within the territorial state of the individual and/or of the crime. Remedies on an international level are scarce and are mostly limited to those available under the American Alien Torts Claims Act. On the ATCA see generally Sascha-Dominik Bachmann, 'Human Rights Litigation against Corporations' (2007) 2 Journal of South African Law 292, 292-308; Sascha-Dominik Bachmann, Civil Responsibility for Gross Human Rights Violations: The Need for a Global Instrument (Pulp, 2007); David P Kunstle, 'Kadic v Karadzic: Do Private Individuals have Enforceable Rights and Obligations under the Alien Tort Claims Act' (1995) 6 Duke Journal of Comparative \& International Law 319, 319-46; Douglas M Branson, 'Holding Multinational Corporations Accountable? Achilles Heels in Alien Tort Claims Act Litigation' [Fall 2010] Santa Clara Journal of International Law; Filartiga v Pena-Irala above n 54; TelOren v Libyan Arab Republic. 726 F 2d 774 US Court of Appeals, DCCir; Kadic v Karadzic 70 F 3d 232 (Court of Appeals 2d Cir 1996); Wiwa v Royal Dutch Petroleum Co, 226 F 3d 88 (2d Cir 2000); Presbyterian Church of Sudan v Talisman Energy, Inc 244 F Supp 2d 331 (SD NY 2005); Sosa v Alvarez-Machain 542 US 692 (2004). But see the Kiobel v Royal Dutch Petroleum decision that claims that corporations as legal entities cannot be subject to ATCA. Kiobel v Royal Dutch Petroleum Co 621 F 3d 111, 120 (2d Cir 2010). For European attempts to use remedies as a tool in protection of human rights, see Caroline Kaeb, 'Emerging Issues of Human Rights Responsibility in the Extractive and Manufacturing Industries: Patterns and 
This was particularly worrisome, because, as mentioned above, TNCs might have been liable not only for the direct actions of the corporation itself, but for the ill-deeds of their suppliers, joint venturers and other groups, including governments, from whose activities they as corporations might have benefited. $^{116}$

Campagna argued that the main reason for the general opposition of the business community to the Norms was not some perceived flaws in the text of the Norms. Rather, it was a substantial flaw in the thinking of business leaders when faced with the prospect of applying international human rights standards to business strategies. She alleged that businesses viewed the need for adherence to IHRL solely as a management issue, whereas, in her opinion, only the question of whether to comply with IHRL constituted a management issue. The more essential question of general human rights compliance resembled a legal issue which should not be left to the discretion of businesses alone to decide. ${ }^{117}$ The Norms therefore represented a major deviation from the self-regulation approach which was more widely accepted and preferred when relations between business and human rights needed to be governed. ${ }^{118}$

Backer regarded the Norms as going even further - altering the foundations of corporate regulation by actually transforming the authority to regulate TNCs. The drastic change in the definition of stakeholders that was embedded in the Norms altered the foundations of corporate governance and regulation. Backer's view was that human rights under the Norms would enter municipal legal systems and international law not from above as part of prescribed international treaty law, but rather from below through private law governing business relations, which would then establish binding rules which in turn would become new customary international law. ${ }^{119}$

The far-reaching character of the Norms drew significant opposition from various states as well. Most states expressed strong reservations, emphasising the undesired departure from the traditional framework of international law,

\footnotetext{
Liability Risks' (2008) 6 Northwestern University Journal of International Human Rights $327,327$.

${ }^{116}$ Hillemanns, above n 9, 1078; Kinley and Chambers, above n 9, 448-9.

${ }^{117}$ Campagna, above n 13, 1229.

${ }^{118}$ Rule, above n 9, 330; Deal, above n 65; Her Majesty's Government of the United Kingdom of Great Britain and Northern Ireland, 'The Responsibilities of Transnational Corporations and Related Business Enterprises with Regard to Human Rights', Communication to the Office of the High Commissioner for Human Rights, Undated [3] <http://www2.ohchr.org/ english/issues/globalization/business/docs/uk.dc>.

${ }^{119}$ Backer, above n 9, 357-8.
} 
and stressing the central role of the state as an actor under international law. ${ }^{120}$ Backer further pointed out that many states indicated that they would be unwilling to accept any legal regime which had the potential to threaten their monopoly of power to adopt and implement international norms within their territory.

Developing states were concerned that the Norms favoured the implementation of human rights standards in their state territory by means of corporate authority rather than state control. ${ }^{121}$ Another concern was that the Norms could reduce incentives for some TNCs to expand their operations into developing states, due to considerations based on the extended liability standard explained above. Such a disincentive to corporate engagement, as well as investment, would have the potential to harm the economic development of these host states. ${ }^{122}$ In general, unlike 'Western' states, which replied to the OHCHR's 'Note Verbale' on the Norms ${ }^{123}$ by emphasising their general disapproval of the document, the developing states tended to remain silent and, apart from Cuba, did not respond to the issue of the Norms

\footnotetext{
${ }^{120}$ But see Permanent Mission of the Federal Republic of Germany to the Office of the United Nations and to the Other International Organizations in Geneva, above n 32.

${ }^{121}$ Backer, above n 9, 374-80.

${ }^{122}$ Rule, above n 9, 331; Deal, above n 65.

123 Office of the High Commissioner for Human Rights, Responsibilities of Transnational Corporations and Related Business Enterprises with Regard to Human Rights, OHCHR Res 2004/116, UN ESCOR, 60 ${ }^{\text {th }}$ sess, 56 ${ }^{\text {th }}$ mtg, Supp No 3, UN Doc E/CN.4/2004/127 (15 March-23 April 2004).
} 
directly. ${ }^{124}$ Cuba, as an exception, supported the Norms as a 'welcomed progressive development of international law'. ${ }^{125}$

Western states voiced concern that shifting responsibility for the implementation of human rights standards to corporations would dilute the primary responsibility of states as legislators of international law. ${ }^{126}$ The United Kingdom argued for a framework containing 'a universally accepted collation and clarification of the minimum standards of behaviour expected of companies with regard to human rights'. ${ }^{127}$ The Australian Government held

the firm view that legal responsibility for the implementation of international human rights standards rests primarily with those States who

\footnotetext{
${ }^{124}$ Facsimile message from the Permanent Mission of the Republic of Croatia to the United Nations Office, 27 September 2004, 'No. 133/04' <http://www2.ohchr.org/english/issues/ globalization/business/docs/croatia.pdf>; Permanent Mission of the Republic of Croatia to the United Nations Office, 'No. 133/04', Communication to the Office of the High Commissioner for Human Rights, 27 September 2004, <http://www2.ohchr.org/english/issues/globalization/ business/docs/croatia.pdf $>$; Philippine Mission to the United Nations and Other International Organizations, 'No. 0297/EAM-2004', Communication to the Office of the High Commissioner for Human Rights, 6 October 2004, <http://www2.ohchr.org/english/ issues/globalization/business/docs/philippines.pdf $>$; Mauritius Mission to the United Nations, 'No. 346/2004 MMG/HR/3/6', Communication to the Office of the High Commissioner for Human Rights, 30 September 2004, <http:/www2.ohchr.org/english/issues/globalization/ business/docs/mauritius.pdf $>$; Permanent Mission of the Syrian Arab Republic to the United Nations Office, 'No. 20/2004', Communication to the Office of the High Commissioner for Human Rights, 12 July 2004, <http://www2.ohchr.org/english/issues/globalization/ business/docs/syria.doc >; but see Republica de Cuba Misión Permanente ante la Oficina de las Naciones Unidas y los Organismos Internacionales, 'Nota Nro. 461', Communication to the Office of the High Commissioner for Human Rights, 12 July 2004, <http://www2.ohchr. org/english/issues/globalization/business/docs/cuba.pdf>

${ }^{125}$ Republica de Cuba Misión, above n 124.

${ }^{126}$ Backer, above n 9, 376; see, eg, European Union, 'EU Reply to the OHCHR Questionnaire on Responsibilities of Transnational Corporations and Related Business Enterprises with Regard to Human Rights', Communication to the Office of the High Commissioner for Human Rights, $2004<$ http://www2.ohchr.org/english/issues/globalization/business/docs/ europeanunion>.

The Norwegian Ministry of Foreign Affairs, above n 93; Facsimile Message from the Permanent Mission of Denmark to the United Nations Office, 1 October 2004, 'Reply of Denmark to the OHCHR Questionnaire on Responsibilities of Transnational Corporations and Related Business Enterprises with Regard to Human Rights' <http://www2.ohchr.org/ english/issues/globalization/business/docs/denmark.pdf>.

${ }^{127}$ Her Majesty's Government of the United Kingdom of Great Britain and Northern Ireland, above $\mathrm{n} 118,4$.
} 
are party to the standards, not individual businesses. Businesses are obliged to comply with the laws of the countries in which they operate. ${ }^{128}$

The Canadian Government recognised that 'companies have an important role to play in the promotion and protection of human rights', but emphasised the primary role of the states in this matter. It also expressed several concerns regarding the Norms - mainly that they purported to extend existing human rights obligations of states to TNCs; entrusted enforcement mechanisms, which may become ineffective, to non-state actors, which in turn could assist states in avoiding their human rights obligations; and changed the existing framework of obligations within the framework of international law. ${ }^{129}$ The United States went even further by claiming that the Norms were not based on existing legal frameworks, that they were 'doomed from the outset' and that the international community should rather focus on assisting states to implement their human rights obligations and enforce national law. ${ }^{130}$ Moreover, they claimed that the Norms represented a significant divergence from the existing frameworks of international law by attempting to impose duties and obligations on non-state actors, while these were applicable solely to states. ${ }^{131}$

There was also some anxiety that the Norms would make TNCs both a subject and a source of international law, thus obliterating traditional boundaries of international law. ${ }^{132}$ Of particular interest was the response of the United States, which began by reiterating the US position that the Norms

have no status - legal or otherwise. Not only was this exercise beyond the mandate of the Sub-Commission - but it was undertaken wholly without consideration for the views of the States.

The United States also refuted the claim that TNCs were responsible for widespread human rights abuses in countries where they operate, claiming that such abuses were the result of 'action or inaction of States'. The United States further alleged that the international community should focus on promoting and enforcing the rule of law by governments and not on 'a drafting exercise geared toward creating "norms" out of whole cloth'. ${ }^{133}$

\footnotetext{
${ }^{128}$ Australian Permanent Mission to the UN, above $\mathrm{n}$ 66; see also a similar response from Norway: The Norwegian Ministry of Foreign Affairs, above n 93.

${ }^{129}$ Permanent Mission of Canada to the Office of the United Nations in Geneva, above $\mathrm{n} 28$.

${ }^{130}$ United States Mission to International Organizations, above n 114.

${ }^{131}$ Ibid; Backer, above n 9, 377.

${ }^{132}$ Backer, above n 9, 288.

${ }^{133}$ United States Mission to International Organizations, above n 114.
} 
These adverse views seriously impacted on the views of other UN Member States when the Norms were considered for adoption by the Commission at its $60^{\text {th }}$ session in 2004. Further work on the norms was consequently put on hold. Later, the OHCHR issued a statement thanking the Sub-Commission for drafting the Norms, confirming the overall importance of the subject, and at the same time clarifying that the draft proposal had no legal status, and therefore the Sub-Commission should not perform any monitoring functions regarding the Norms. ${ }^{134}$ Subsequently, the Norms were effectively abandoned by the Commission on Human Rights in its $61^{\text {st }}$ session in 2005, in line with the approach led by the United States and Australia. The Commission recommended that the UN General Secretary should appoint a Special Representative to review the whole matter of corporations and human rights. ${ }^{135}$ Consequently, in July 2005, Harvard Professor John Ruggie was appointed as the Special Representative to the UN Secretary General. ${ }^{136}$

In their present form, the Norms have no binding force in international law. The Sub-Commission which drafted the Norms was not mandated to create binding new international law. At present, there is no international treaty which incorporates the Norms, nor is there evidence of any evolving state practice indicating the development of customary international law to that effect. Moreover, as mentioned above, the Commission itself stated that the Norms should have no legally binding effect. However, already existing principles of customary international law which were restated in the Norms retain their force as independent principles of international law. ${ }^{137}$

\section{The Norms AND Ruggie’s 'Protect, Respect AND REMEDY' FRAMEWORK}

One cannot avoid reassessing the value and the potential of the Norms in light of the newly endorsed Guiding Principles and the 'Protect, Respect and Remedy' framework developed by Ruggie. Despite the fact that Ruggie distanced himself from the Norms, there were two important lessons learnt

\footnotetext{
${ }^{134}$ Office of the High Commissioner for Human Rights, above n 123; Kinley and Chambers, above n 9, 458-9; Vázquez, above n 18, 929; Weissbrodt, above n 13, 68-70; Baxi, above n $20,2$.

${ }^{135}$ Backer, above n 9, 288, 331-3; Ruggie, above n 6, 821; Kinley and Chambers, above n 9, 449, 459; Martin-Ortega, above n 9, 281.

${ }^{136}$ Ruggie, above n 6, 821 .

${ }^{137}$ Kinley and Chambers believe that the Norms are an example of international 'soft law' that may become 'hard law' if and when there is enough evidence of state practice and additional evidence of opinio juris or if they are incorporated through unilateral declarations of commitments. Kinley and Chambers, above n 9, 482-8; Backer, above n 9, 380-1.
} 
from the process of drafting the Norms: firstly that any future legal document governing the sensitive issue of business and human rights had to be acceptable to all affected stakeholders and had to avoid creating a framework of hard law rules. A more thorough analysis of the Guiding Principles, however, suggests that the difference between the two documents is only a matter of nuance and that their principles, while constituting clearly nonbinding 'soft law', may eventually lead to the future development of recognised 'hard law'. ${ }^{138}$

Ruggie, the SRSG, went to great lengths to dissociate his work from the original Norms. He harshly criticised the Norms in a 2006 report to the Human Rights Council, a criticism referred to by some commentators as the 'death knell' for the Norms. ${ }^{139}$ While the SRSG appraised the content of the Norms as such, he emphasised the flaws in their nature and form. He claimed that the two most problematic aspects of the Norms were the legal authority envisaged for them and the proposed sharing of human rights responsibilities between states and businesses. Ruggie essentially argued that the Norms, while on the one hand creating a new body of international law that addressed corporations directly, were at the same time lacking definition when elaborating on joint obligations which were shared by states and corporations. ${ }^{140}$ The SRSG wrote that the Norms could not simultaneously merely reflect existing international law and, be directly binding upon corporations. This would in effect be breaking with generally accepted principles of international law, which do not grant international legal personality to corporations. (The possible exception to this principle is the arguable responsibility of corporations, in certain circumstances, for aiding and abetting breaches of jus cogens human rights and the law of armed conflict). Ruggie further argued that the Norms failed to differentiate between the responsibilities of states and those of businesses according to their respective social roles and duties. This argument was linked to the observation that this might lead to a situation where the duty to protect human rights might fall entirely upon corporations, hence enabling states to avoid their own

\footnotetext{
138 United Nations Human Rights Council, 'Report of the Special Representative of the Secretary-General' above $\mathrm{n} 2$.

${ }^{139}$ Bart Mongoven, 'The Death of the UN Norms' (10 March 2006), Stratfor; Gareth Sweeney, 'Transnational Corporations: Principled Pragmatism' or Mere Antagonism?' (18 September 2006); Kinley and Chambers, above n 9, 460; Emeka Duruigbo, 'Corporate Accountability and Liability for International Human Rights Abuses: Recent Changes and Recurring Challenges' (2008) 6 Northwestern University Journal of International Human Rights 222, 244; see also David Weissbrodt, 'UN Perspectives on 'Business and Humanitarian and Human Rights Obligations' (2006) 100 Proceedings of the Annual Meeting (American Society of International Law) 135, 138-9.

${ }^{140}$ Ruggie, above n 19, 56-9; Ruggie, above n 6, 822; Kinley and Chambers, above n 9, 460.
} 
responsibilities. This is a development which can be witnessed already today in the context of CSR in the developing world: MNCs take on the role of the host nation in respect to the provision of basic social services. Ruggie observed this possibility in light of the legal discussion surrounding the term 'spheres of influence', a concept which he considered to have no legal pedigree. He therefore concluded that the Norms should be abandoned altogether rather than followed. ${ }^{141}$

Ruggie's approach was criticised by the civil society proponents of the Norms who believed that the SRSG's focus should have been on developing the Norms rather than on abandoning them. ${ }^{142}$ Weissbrodt criticised Ruggie for a potential corporate bias, stating that the SRSG's critique of the Norms was 'inspired, if not copied word for word, from the advocacy of the International Chamber of Commerce and the International Organization of Employers'. ${ }^{143}$

Different views were expressed by various states. Argentina, for example, was worried that the Norms weakened the social capabilities of states in regard to human and social rights. Liechtenstein, on the other hand, applauded the SRSG for his approach of 'principled pragmatism' which succeeded where the Norms had failed. ${ }^{144}$

\footnotetext{
${ }^{141}$ Kinley and Chambers, above $\mathrm{n} 9,450$.

${ }^{142}$ Letter from 92 NGOs and 15 Individuals to John Gerard Ruggie, 18 May 2006, 'Joint NGO Letter in Response to Interim Report 1'. Ruggie in his response letter argued that 'the success of any long-term strategy hinges on getting the basics right and then building step-by-step on that foundation.' He also claimed that ' $[\mathrm{t}]$ he choice of verbs in the resolution outlining the mandate indicates that it is intended in the first instance to be a ground-clearing effort.' Letter from John Gerard Ruggie to 92 NGOs and 15 Individuals, 22 May 2006, 'Re: Joint NGO Response to Interim Report'. See also the similar responses from Amnesty International, Realizing Right, Earthrights International, FIDH and Oxford Analytica. Irene Khan to John Gerard Ruggie, 27 April 2006, 'Letter from Amnesty Intl. Secretary General'; Mary Robinson, 'Commentary on the Interim Report of the Special Representative on Business and Human Rights' (Realizing Rights, 31 March 2006); Earthrights International, 'Ominous Outlook for the UN Norms | EarthRights International' (Earthrights, 22 March 2006); International Federation for Human Rights, 'Comments to the Interim Report of the Special Representative of the Secretary-General on the Issue of Human Rights and Transnational Corporations and Other Business Enterprises' (Position Paper, 15 March 2006); Oxford Analytica Ltd, 'INTERNATIONAL: Human Rights/Business Report Divides' (Text, 14 March 2006). Kinley and Chambers, above n 9, 461; see also Duruigbo, above n 139, 244; Sweeney, above n 139, 8; Karsten Nowrot, 'The 2006 Interim Report of the UN Special Representative on Human Rights and Transnational Corporations: Breakthrough or Further Polarization?'(Policy Paper 2, March 2006).

${ }^{143}$ Weissbrodt, above n 139, 138.

${ }^{144}$ Business \& Human Rights Resource Centre, 'Discussion of Ruggie's Interim Report by UN Human Rights Council’ (Business-HumanRights.org, 25 September 2006).
} 
While the Norms were supposed to increase corporate responsibility for human rights compliance through the introduction, implementation and enforcement of binding human rights principles, thus following an enforcement approach, Ruggie's framework follows the management approach. ${ }^{145}$ While the Norms focused on the benefits and harm that corporations can cause, the SRSG focuses solely on the potential benefits of the corporate presence in the state that hosts its business operations. His approach emphasises the importance of good corporate governance, as 'markets work optimally only if they are embedded within rules, customs and institutions'. ${ }^{146}$ Ruggie argues that history shows that the greatest dangers from corporations come from those that are beyond the reach of the institutional underpinning. ${ }^{147}$

This doctrinal and normative difference between the Norms and Ruggie's framework is the most apparent difference between the two frameworks. While the essential rules and principles set up in the Norms have remained the same in Ruggie's framework, their nature, impact and format have changed. Whereas the drafters of the Norms were content with a declaration reiterating the central role of states in the protection of human rights, Ruggie has stressed this role as a key principle in order to prevent states from delegating the burden of human rights protection to corporations. Ruggie has chosen to limit the range of specific human rights responsibilities applicable to corporations, while reiterating the view that there exists an overall responsibility to respect virtually all internationally recognised human rights. In essence, Ruggie has chosen to implement all the rules of the Norms by adopting Article 10 of the Norms - namely the responsibility of business enterprises to respect human rights in general. He has therefore adopted the normative background of the Norms as his own approach. This conceptual amendment and adaptation has enabled states and the business community to accept the new principles.

Despite the fact that both the drafters of the Norms and the SRSG included various stakeholders in the drafting process, the impact of, and recognition given to, the various groups of contributors differed. The drafters of the

\footnotetext{
${ }^{145}$ Jonas Tallberg, 'Paths to Compliance: Enforcement, Management, and the European Union' (2002) 56 International Organization 609, 611-13; Tanja A Börzel, T Hofmann, and C Sprungk, 'Why Do States Not Obey the Law? Lessons from the European Union' (Paper Prepared for the EUSA Conference, Nashville, 27-30 March 2003) 15-16.

146 John Gerard Ruggie, Promotion and Protection of all Human Rights, Civil, Political, Economic, Social and Cultural Rights, including the Right to Development-Protect, Respect and Remedy: A Framework for Business and Human Rights. A Report of the Special Representative of the Secretary-General on the Issue of Human Rights and Transnational Corporations and other Business Enterprises, UN Doc A/HRC/8/5 (7 April 2008) [2].

${ }^{147}$ Ibid.
} 
Norms aimed at creating a document that would define legally the duties of business enterprises in relation to human rights, and therefore focused on the opinions of academic scholars and civil society. Ruggie's strategic choice was to create a framework acceptable to businesses and states. Consequently, he included these actors in the drafting process, considering them crucial and fundamental for its success, while limiting the role and importance of representatives from civil society.

In conclusion, it can be submitted that work on both frameworks has turned out to be interconnected: the Norms set the high normative standard which laid down the groundwork for Ruggie's eventual success in promoting his Guidelines as a widely acceptable framework.

\section{CONCLUSION}

This article has discussed the question of why the Norms ultimately failed to win the approval of the UN Commission on Human Rights. It suggests that the eventual abandoning of the Norms was caused by a number of factors, which centred on the potential effects of the framework of the Norms, rather than only their substance. These reasons are well documented in the reservations and the criticism raised by states and representatives of the business community. The main criticisms were: that the Norms subjected TNCs to direct obligations under international law without the express consent of the states; that existing human rights instruments were overstretched by their application directly to TNCs; that the Norms were nonvoluntary; that they disempowered the states and enlarged the legal role of corporations; that they were vague; and that they contained allegedly ineffective anti-democratic enforcement mechanisms.

In conclusion, it is submitted that the reasons for the failure of the Norms can be generally divided into three groups. Firstly, the novel character and the large scope of new legal concepts within the framework of the Norms broke with traditional roles of subjects under international law. They thus enabled states and business organisations to claim that the Norms were contrary to the positivist foundations of international law. Secondly, the scope of the Norms went too far in blurring the distinction between public and private law frameworks, therefore giving room to the argument that the new concepts countermanded the fundamental role of the state as legislator. Finally, the legal vagueness of the Norms and the contradictions within the Norms assisted the case against their endorsement and led to their eventual dismissal. Some of these crucial faults of the Norms should be further emphasised. A central issue was the planned degrading of states as the main subjects of international 
law, by a curtailment of their legislative sovereignty and authority. Vázquez observed that the Norms created a framework which promoted a factual disempowerment of the states. ${ }^{148}$ The factors motivating TNCs and other nonstate actors to comply with the Norms may differ from those motivating states, and TNCs' interests may even be at odds with the interests of states: business operations may follow different rules from the operations of states. Vázquez also observed that violations of international law of the kind found in the Norms may have a jurisgenerative effect, and therefore we should abandon the norms which should still be developed free from any rigid enforcement mechanism and only use such mechanisms with clear norms that are not to be changed. ${ }^{149}$

As mentioned, the Norms blurred the line between public and private law, and moved in the direction of transnational law, by elevating TNCs to subjects of international law. In that they went further than other initiatives dealing with the relations between business and human rights. Backer believed that the Norms treated the TNCs as subjects of international law, rather than as objects, a significant modification which altered the regulatory power between state and non-state actors. ${ }^{150}$ This character of the Norms was largely resisted by states. The UK submitted a document to the OHCHR stating that

[a]ny ongoing process should not seek to place companies in the same position as States with regard to obligations in international human rights law. To avoid confusion of their legal status, texts relating to the responsibilities of business with regard to human rights should not use legally-binding treaty language. ${ }^{151}$

Perhaps the main reason that the Norms were opposed so fiercely by a wide coalition of critics was that they 'touched the heart of the matter'. They questioned the very essence of the state-centred doctrine ${ }^{152}$ through imposing direct legal obligations on TNCs and structuring a role for TNCs that bypassed the states and subjected them to supranational regulation monitored

\footnotetext{
148 Generally, all obligations disempower the states, as they limit their sovereignty and freedom of action. In this case, states also lose power as new institutions may be installed to promote compliance with the Norms, apart from leaving the issue of compliance to the will of the states (even though at times collective).

${ }^{149}$ Vázquez, above n 18, 950-2.

${ }^{150}$ Backer, above n 9, 375-6.

${ }^{151}$ Her Majesty's Government of the United Kingdom of Great Britain and Northern Ireland, above n 118, 3; see also the Australian view that guidelines for CSR should be voluntary and that the Norms represent a major shift from voluntary adherence: Australian Permanent Mission to the UN, above $\mathrm{n} 66$.

${ }^{152}$ Duruigbo, above n 139, 233-5.
} 
through non-state enforcement mechanisms. The Norms were different from all other frameworks intended to deal with the business and human rights relationship; they were not just moderate adjustments of the inefficient system of state regulation of TNCs. They tried to use the international legal framework as a basis for private law making. This was an attempt to rejoin the public and private legal systems into a single framework of transnational law, similar to the frameworks that existed prior to the Peace of Westphalia. Such a significant alteration of the framework of international law would represent a crucial divergence from the exclusive, state-monopolised international legal system to an inclusive transnational system with various legal subjects. This change was well understood by the (mainly Western) states, an understanding reflected in their extreme criticism of the project.

One can compare the introduction of the Norms into the ruling paradigm of voluntary initiatives - a paradigm which maintains the state-centred order with an alternative, presented at the time, of what Kuhn relates to as 'normal science'. ${ }^{153}$ This brings us to the wider question posed at the beginning of this article: whether there was a possibility of creating 'hard law' in the framework of international law, to regulate the relations between business and human rights. If we adhere to Kuhn's view, then the situation must become a crisis before there will be a destructive-constructive paradigm change. It seems that reality confirms this assumption. One of the key objections to the Norms was that they were more than the 'soft law' document that their drafters presented them as. Neither the business community, nor most of the states were ready to accept the creation of binding international law regulating corporations, which would not only bypass the states but which would attempt to coerce them from below. These objections, however, may be the result of the joining of various (over-) ambitious intentions in the Norms, and may not necessarily predict the failure of all future 'hard law' initiatives. There are indications that the Norms went too far, but they may have suggested a solution to a problem that would otherwise have remained unanswered. Perhaps, as Kuhn would predict, there needs to be a new 'crisis' — an extreme situation that clarifies the failure of the current voluntary and selfregulating frameworks - in order for the new paradigm to be advanced.

The question of the failure of the Norms should therefore be limited to their formal scope. On a normative level, the Norms may turn out to be (at least) a partial success. Despite the failure of not having become binding law, the Norms created a significant impact on stakeholders at the non-state level. Investment institutions began applying the Norms to persuade companies to

\footnotetext{
153 Thomas S Kuhn, The Structure of Scientific Revolutions (University of Chicago Press, $2^{\text {nd }}$ enlarged ed, 1970) vol 1, 2, 24.
} 
improve their social responsibility; NGOs began using the Norms as a basis for their advocacy of corporate social responsibility; companies have expressed general support for the Norms, while others even began 'roadtesting' the Norms. ${ }^{154}$ Perhaps, after all, the Norms are fulfilling the role designed for them, even if they were not adopted officially. Despite being considered the less preferred alternative by the corporations, they have certainly turned out to be one of the fundamental building blocks of the new UN 'Protect, Respect and Remedy' framework. Rule suggested that the Norms were designed to stimulate societal change rather than to become a binding legal document, and that they should therefore be read as relating to an ideal structure of de lege ferenda regarding the connection between business and human rights. ${ }^{155}$ Backer argued that the Norms were constructed so as to have a certain constitutional dimension on a supra-national level. ${ }^{156}$ One can conclude by endorsing the view of Baxi, who said that the more successful attempts to legislate have often been the ones where the original ambitions constituted legal utopias 'de lege ferenda', which managed to transform existing legal and factual frameworks. ${ }^{157}$

\footnotetext{
${ }^{154}$ Weissbrodt, above $\mathrm{n} 13,72-3$.

${ }^{155}$ Rule, above n 9, 332.

${ }^{156}$ Backer, above n 9, 373.

${ }^{157}$ Baxi, above n 20, 14-15.
} 